\title{
Complex evaluation of porosity in A356 aluminium alloy using advanced porosity module
}

Marek Brůna, Lukáš Kucharčík, Augustín Sládek

Department of technological engineering, University Of Žilina, Univerzitná 1, 01001 Žilina, Slovak Republic, marek.bruna@fstroj.uniza.sk

In this work, the formation of porosity (micro, macro porosity and pipe shrinkage) has been examined under different casting conditions aimed at manipulating cooling rate and pouring temperature of aluminium alloy A356. The results of the experiment will attempt to verify that the solidification rate and pouring temperature have an effect on the formation and character of gas pores in castings from A356 alloy. For this purposes was used advanced porosity module integrated into simulation software ProCAST. Specific casting and mold was designed to be able observe porosity formation. Main aim was to choose the right shape, so all types of porosity occur during solidification. Top part of casting is optimized for creation of pipe shrinkage. Bottom part connected with top part through narrowed area (which will solidifies first and additional feeding will not be possible) is ideal for formation of internal micro and macroporosity.

Keywords: simulation, porosity, aluminum alloys

\section{Acknowledgements}

This work was created within the solution of the grant project VEGA no. 1/0610/12, VEGA no. 1/0785/13 focusing on technology and simulation for applications in manufacturing and KEGA no. 006ŽU-4/201. The authors thank the Grant Agency for support.

\section{References}

[1] CAMPBELL, J. (2003). Castings. Vol. 2, Butterworth - Heinemann, Oxford, pp. 242 - 255. ISBN 978-0750647908.

[2] HUANG, L.W., SHU, W.J., SHIH, T.S. (2000). Diagnosis and analysis of oxide films on alloys Al-Mg-Si. AFS Transactions, 108. Pp. $547-561$.

[3] PASTIRČÁK, R., URGELA, D. (2010). Production of casting molds for computer-controlled basis. In: Quo vadis foundry III. Ecological aspects of metallurgy and foundry. Košice, HF TU Košice. Pp. 148-152. ISBN 978-80-553-0506-6.

[4] BRŮNA, M., SLÁDEK, A. (2011): New trends in numerical simulations for casting. In: Technológ: Journal for the theory and practice of mechanical technology. EDIS, Žilina. Pp. 27-30. ISSN 1337-8996.

[5] BRŮNA, M., BOLIBRUCHOVÁ, D. (2010). Analysis of the impact of the thickness of the filter medium on reoxidation processes using computer simulation. In: Quo vadis foundry III. Ecological aspects of metallurgy and foundry. Košice, HF TU Košice. Pp. 28 - 34. ISBN 978-80-553-0506-6.

[6] PASTIRČÁA, R., URGELA, D. (2011). Device for production of prototype moulds by milling. In: Archives of foundry engineering, 2011, Vol. 11, Spec. Issue 1. pp. 45-50. ISSN 1897-3310

[7] BOLIBRUCHOVÁ, D. (2012). Properties, production, and industrial application of aluminium foam. In: Technológ: časopis pre teóriu a prax mechanických technológií, issue. 2. Pp. 111-116. ISSN 1337-8996.

[8] MEDLEN, D., BOLIBRUCHOVÁ, D. (2012). The influence of remelting on the properties of AlSi6Cu4 alloy modified by antimony. In: Archives of foundry Engineering, January-march. Pp. 81-86, vol. 12. ISSN 1897-3310.

[9] KANTORÍK, R., BOLIBRUCHOVÁ, D. (2011). Free melt surface monitoring with the help of metal flow simulation in moulds. In: International Foundry Research. Vol. 63, issue 2. Pp. 18 - 23. ISSN 0046-5933.

[10] SLÁDEK, A., BOLIBRUCHOVÁ, D., PASTIRČÁK, R., VAŠKO, I. (2010). The influence of antimony on the properties of AlSi7Mg0.3 alloy. In: Proceedings of $6^{\text {th }}$ world foundry congress: Hangzhou China. Pp $261-266$.

[11] WEISS, V., STRIHAVKOVA, E. (2012). Influence of the homogenization annealing on microstructure and mechanical properties of AlZn5.5Mg2.5Cu1.5 alloy. In: Manufacturing Technology, Volume 12, pp. 297 - 302. ISSN 1213-2489.

[12] MICHALCOVÁ, A., VOJTECH, D. (2012). Structure of rapidly solidified aluminium alloys. In: Manufacturing Technology, Volume 12, pp. 166 - 169. ISSN 1213-2489. 